Jurnal Cendekia Akuntansi

Volume 2, Nomor 2

Kediri, Desember 2021

\title{
DAMPAK GOOD CORPORATE GOVERNANCE SEBAGAI MODERASI DALAM HUBUNGAN FINANCIAL PERFORMANCE TERHADAP FIRM VALUE DI MASA PANDEMI COVID 19
}

\author{
Sugeng Hariadi \\ Sekolah Tinggi Ilmu Ekonomi (STIE) Malangkuçeçwara Malang \\ E-mail: hariadisg@yahoo.com
}

\begin{abstract}
Abstrak
Fokus dalam penelitian ini adalah perusahaan sektor Food and Baverage yang terdaftar di Bursa Efek Indonesia di tahun selama 2020 saat awal pandemi di Indonesia. Penelitian ini bertujuan : (1) untuk menganalisis pengaruh kinerja keuangan perusahaan terhadap Firm Value di masa pandemi (2) untuk menganalisis Good Corporate Governance dapat memoderasi hubungan pengaruh kinerja keuangan terhadap Firm Value di masa pandemi. Dengan menggunakan Analisis Regresi Linier Sederhana dalam analisis yang pertama dan menggunakan MRA dalam analisis yang kedua dengan program SPSS. Hasil dari penelitian ini : (1) adanya pengaruh yang positif signifikan antara kinerja keuangan terhadap nilai perusahaan, (2) Good Corporate Governance tidak memoderasi hubungan antara kinerja keuangan terhadap nilai perusahaan.
\end{abstract}

Kata kunci : Good Corporate Governance, Kinerja Keuangan, Nilai Perusahaan.

\begin{abstract}
The focus in this study is the Food and Baverage sector companies listed on the Indonesia Stock Exchange in 2020 at the beginning of the pandemic in Indonesia. This study aims: (1) to analyze the influence of the company's financial performance on Firm Value during the pandemic (2) to analyze that Good Corporate Governance can moderate the relationship between the influence of financial performance on Firm Value during the pandemic. By using Simple Linear Regression Analysis in the first analysis and using MRA in the second analysis with the SPSS program. The results of this study: (1) there is a significant positive influence between financial performance on firm value, (2) Good Corporate Governance does not moderate the relationship between financial performance and firm value.
\end{abstract}

Kata kunci : Company Value, Financial Performance, Good Corporate Governance. 


\section{PENDAHULUAN}

Industri makanan dan minuman merupakan industri yang terpengaruh oleh kondisi pandemi covid 19 di Indonesia. Hal ini dikarenakan banyak perusahaan sektor ini tidak dapat mempekerjakan karyawannya secara jam kerja penuh dan banyak menghentikan produksinya. Pada masa sebelum pandemi, industri yang berkembang pesat sektor barang konsumsi (Good Consummer Industry) secara signifikan karena optimisme dari investor (Fajrian, 2019). Oleh karenanya persaingan dalam menarik investasi adalah sangat kompetitif dan harus didukung dengan penyajian laporan keuangan yang lengkap. Pihak investor mengamati kinerja keuangan sebagai alat mengevaluasi dari investasi yang ditanamkan. Dan Good Corporate Governance merupakan upaya perusahaan dalam meningkatkan tata kelola perusahaan yang baik. Dengan adanya GCG ini akan dapat mempererat hubungan kinerja perusahaan dengan firm value. Firm Value atau Nilai perusahaan dapat juga dijadikan parameter untuk peningkatan kemakmuran perusahaan. Penelitian sebelumnya menyatakan bahwa Kinerja Keuangan berpengaruh positif terhadap nilai perusahaan (Wijaya, 2019), dan dalam penelitian yang lain menyatakan bahwa kinerja keuangan berpengaruh terdahap nilai perusahaan karena perusahaan dalam keadaan laba sehingga nilai perusahaan akan semakin tinggi (Mufidah, 2018).

Dalam pengambilan keputusan, investor membutuhkan informasi yang valid, tepat waktu dan lengkap terkait pengelolahan dan kinerja perusahaan. Informasi yang dimaksud yaitu informasi keuangan dan non-keuangan yang dapat mempengaruhi suatu nilai perusahaan. GCG merupakan informasi nonkeuangan tentang tata kelola perusahaan. $G C G$ digambarkan dengan laporan komite audit, dewan komisaris independen dan kepemilikan managerial.

Penelitian dilakukan oleh (Puspitasari, 2019) menyatakan GCG diproksikan dewan komisaris tidak memoderasi pengaruh profitabilitas terhadap nilai perusahaan sama halnya dengan penelitian (Mufidah, 2018). Hal ini bertentangan dari penelitian (Bintara, 2018) bahwa terdapat interaksi pengaruh signifikan positif profitabilitas dan Good Corporate Governance terhadap nilai perusahaan. Dengan adanya perbedaan hasil penelitian terdahulu tersebut maka peneliti tertarik meneliti ulang pada situasi terjadinya awal pandemi yaitu tahun 2020 . Perbedaan periode penelitian ini tahun 2020 yang berbeda dengan peneliti sebelumnya dan penelitian ini menggunakan obyek industry food and baverage terdaftar di Bursa Efek Indonesia. Selain itu juga menambahkan komite audit sebagai moderasi Berdasarkan penjelasan tersebut maka peneliti tertarik mengambil judul Efek Moderasi $G C G$ dalam Pengaruh Faktor Kinerja Keuangan Perusahaan Terhadap Firm Value (Study pada Perusahaan Industri Food and Baverage di Bursa Efek Indonesia Pada tahun 2020).

Penelitian ini bertujuan untuk menganalisis Faktor Kinerja Keuangan Perusahaan berpengaruh signifikan terhadap Nilai Perusahaan, dan untuk menganalisis apakah GCG dengan proksi kepemilikan manajerial, dewan komisaris independen, dan komite audit dapat memoderasi pengaruh Kinerja Keuangan terhadap Nilai Perusahaan. 


\section{TINJAUAN PUSTAKA}

Industri makanan dan minuman merupakan industri yang terpengaruh oleh kondisi pandemi covid 19 di Indonesia. Hal ini dikarenakan banyak perusahaan sektor ini tidak dapat mempekerjakan karyawannya secara jam kerja penuh dan banyak menghentikan produksinya. Pada masa sebelum pandemi, industri yang berkembang pesat sektor barang konsumsi (Good Consummer Industry) secara signifikan karena optimisme dari investor (Fajrian, 2019). Oleh karenanya persaingan dalam menarik investasi adalah sangat kompetitif dan harus didukung dengan penyajian laporan keuangan yang lengkap. Pihak investor mengamati kinerja keuangan sebagai alat mengevaluasi dari investasi yang ditanamkan. Dan Good Corporate Governance merupakan upaya perusahaan dalam meningkatkan tata kelola perusahaan yang baik. Dengan adanya GCG ini akan dapat mempererat hubungan kinerja perusahaan dengan firm value. Firm Value atau Nilai perusahaan dapat juga dijadikan parameter untuk peningkatan kemakmuran perusahaan. Penelitian sebelumnya menyatakan bahwa Kinerja Keuangan berpengaruh positif terhadap nilai perusahaan (Wijaya, 2019), dan dalam penelitian yang lain menyatakan bahwa kinerja keuangan berpengaruh terdahap nilai perusahaan karena perusahaan dalam keadaan laba sehingga nilai perusahaan akan semakin tinggi (Mufidah, 2018).

Dalam pengambilan keputusan, investor membutuhkan informasi yang valid, tepat waktu dan lengkap terkait pengelolahan dan kinerja perusahaan. Informasi yang dimaksud yaitu informasi keuangan dan non-keuangan yang dapat mempengaruhi suatu nilai perusahaan. GCG merupakan informasi nonkeuangan tentang tata kelola perusahaan. $G C G$ digambarkan dengan laporan komite audit, dewan komisaris independen dan kepemilikan managerial.

Penelitian dilakukan oleh (Puspitasari, 2019) menyatakan GCG diproksikan dewan komisaris tidak memoderasi pengaruh profitabilitas terhadap nilai perusahaan sama halnya dengan penelitian (Mufidah, 2018). Hal ini bertentangan dari penelitian (Bintara, 2018) bahwa terdapat interaksi pengaruh signifikan positif profitabilitas dan Good Corporate Governance terhadap nilai perusahaan. Dengan adanya perbedaan hasil penelitian terdahulu tersebut maka peneliti tertarik meneliti ulang pada situasi terjadinya awal pandemi yaitu tahun 2020 . Perbedaan periode penelitian ini tahun 2020 yang berbeda dengan peneliti sebelumnya dan penelitian ini menggunakan obyek industry food and baverage terdaftar di Bursa Efek Indonesia. Selain itu juga menambahkan komite audit sebagai moderasi Berdasarkan penjelasan tersebut maka peneliti tertarik mengambil judul Efek Moderasi $G C G$ dalam Pengaruh Faktor Kinerja Keuangan Perusahaan Terhadap Firm Value (Study pada Perusahaan Industri Food and Baverage di Bursa Efek Indonesia Pada tahun 2020).

Penelitian ini bertujuan untuk menganalisis Faktor Kinerja Keuangan Perusahaan berpengaruh signifikan terhadap Nilai Perusahaan, dan untuk menganalisis apakah $G C G$ dengan proksi kepemilikan manajerial, dewan komisaris independen, dan komite audit dapat memoderasi pengaruh Kinerja Keuangan terhadap Nilai Perusahaan. 
Kerangka Konseptual

Gambar 1. Model Kerangka Konseptual

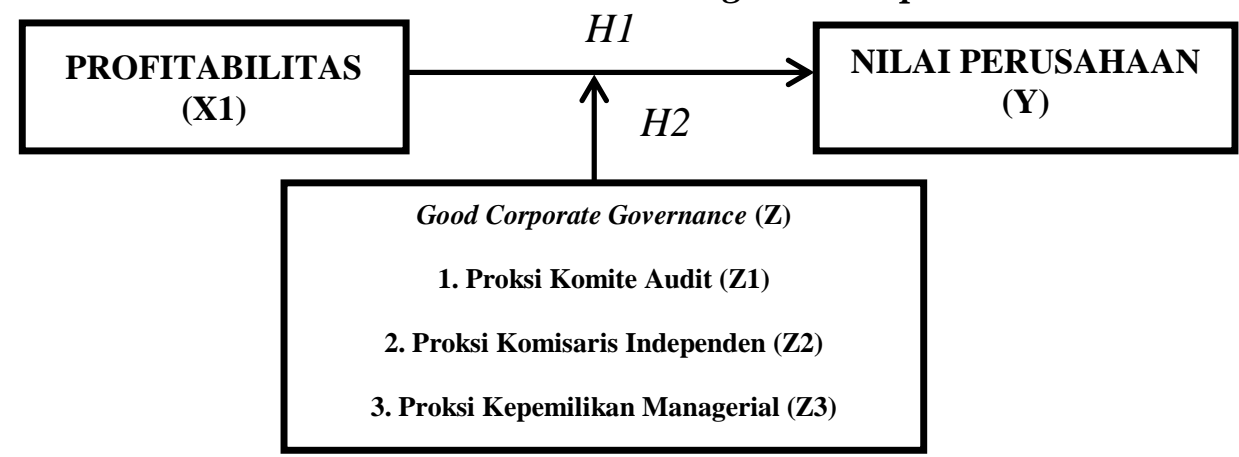

\section{Hipotesis Penelitian}

H1: Profitabilitas berpengaruh signifikan terhadap nilai perusahaan

H2: $G C G$ dapat memoderasi pengaruh profitabilitas terhadap nilai perusahaan.

\section{METODE PENELITIAN}

\section{Jenis Penelitian}

Jenis penelitian ini adalah penelitian kuantitatif dengan menggunakan pendekatan korelasional kausalitas. Bertujuan untuk mengetahui hubungan antara variabel pemoderasi yaitu $G C G$ dengan variabel independen dan dependen.

\section{Metode Pengumpulan Data} pustaka.

Metode pengumpulan data yang digunakan adalah dokumentasi dan studi

\section{Variabel dan Pengukuran}

1. Variabel Dependen (Nilai Perusahaan)

Nilai perusahaan digambarkan dengan harga pasar sahamnya. Jika harga saham tinggi maka semakin tinggi pula nilai dari perusahaan. Nilai Perusahaan dalam penelitian ini diukur dengan menggunakan ratio PBV berikut rumus :

$$
\text { PBV }=\frac{\text { Market } \text { Price per Share }}{\text { Book Value per Share }} \times 100 \%
$$

2. Variabel Independen (Profitabilitas)

Variabel ini menggunakan ratio ROA untuk pengukur keberhasilan perusahaan dalam menghasilkan laba serta dapat menggambarkan tingkat keefektifan dalam menilai kinerja perusahaan sebagai keuntungan bagi investor. Tingkat profitabilitas dengan menggunakan ratio ROA perbandingan laba bersih dengan total Aset.

$$
\mathrm{ROA}=\frac{\text { Laba bersih } \text { setelah pajak }}{\text { Total aset }} \times 100 \%
$$


3. Variabel Moderasi (Good Corporate Governance)

Variabel ini menggunakan proksi komisaris independen, kepemilikan manajerial, dan komite audit dalam menentukan pengungkapan Good Corporate Governance.

a. Pengukuran atas komisaris independen dalam (Hariadi, 2021) diukur ratio menggunakan perbandingan antara jumlah komisaris independen dengan total dewan komisaris independen di perusahaan.

$$
\mathrm{KI}=\frac{\text { Jumlah komisaris independen }}{\text { Total dewan komisaris }} \times 100 \%
$$

b. Proksi Kepemilikan Manajerial,pengukuran kepemilikan manajerial dengan ratio membandingkan jumlah saham pihak manajemen dan saham yang beredar.

$$
\mathrm{KM}=\frac{\text { Jumlah saham pihak manajeraial }}{\text { Saham yang beredar }} \times 100 \%
$$

c. Komite audit dalam (Sarafina, 2017) dengan perhitungan komite audit independen menggunakan ratio komisaris independen dalam komite audit dengan total anggota komite audit.

$$
\mathrm{KA}=\frac{\text { Komisaris Independen dalam komite audit }}{\text { Total komite audit }} \times 100 \%
$$

\section{Populasi dan Sampel}

Populasi yang dipakai adalah Perusahaan sektor Food and Baverage yang terdaftar di Bursa Efek Indonesia tahun 2020. Dengan total populasi 32 perusahaan dan dijadikan sebagai sample semua, sehingga total populasi sama dengan total sampel.

\section{Metode Analisis Data}

Metode yang dilakukan dengan Statistik Deskriptif, Uji Asumsi Klasik meliputi Uji Normalitas, Uji Multikolinieritas, Uji Heteroskedastisitas dan Uji Autokorelasi. Untuk mengetahui kelayakan model regresi dalam penelitian ini. Untuk analisis regresi menggunakan Analisis Regresi Linier Sederhana dan Moderated Regression Analysis (MRA).

\section{HASIL PENELITIAN DAN PEMBAHASAN}

\section{Uji Normalitas}

Tabel 1. Hasil Uji Normalitas - Kolmogrov Smirnov

\begin{tabular}{lrr}
\hline \multicolumn{3}{c}{ One-Sample Kolmogorov-Smirnov Test } \\
\hline \multicolumn{2}{c}{ Unstandardized Residual } \\
\hline $\mathrm{N}$ & 32 \\
\hline Normal Parameters $^{\mathrm{a}, \mathrm{b}}$ & Mean & .0000000 \\
\hline
\end{tabular}




\begin{tabular}{|c|c|c|}
\hline & $\begin{array}{l}\text { Std. } \\
\text { Deviation }\end{array}$ & 58.63972764 \\
\hline \multirow{3}{*}{$\begin{array}{l}\text { Most Extreme } \\
\text { Differences }\end{array}$} & Absolute & .097 \\
\hline & Positive & .094 \\
\hline & Negative & -.097 \\
\hline \multicolumn{2}{|l|}{ Test Statistic } & .097 \\
\hline \multicolumn{2}{|c|}{ Asymp. Sig. (2-tailed) } & $.200^{\mathrm{c}, \mathrm{d}}$ \\
\hline \multicolumn{3}{|c|}{ a. Test distribution is Normal. } \\
\hline \multicolumn{3}{|c|}{ b. Calculated from data. } \\
\hline \multicolumn{3}{|c|}{ c. Lilliefors Significance Correction. } \\
\hline \multicolumn{3}{|c|}{$\mathrm{d}$. This is a lower bound of the true significance. } \\
\hline
\end{tabular}

Berdasarkan hasil dari tabel 1 dengan menunjukkan angka Sig 0.200 dapat dikatakan bahwa data berdistribusi normal.

\section{Uji Multikolinieritas}

Tabel 2. Hasil Uji Multikolinieritas

\begin{tabular}{llll}
\hline \multicolumn{4}{c}{ Coefficients $^{\mathbf{a}}$} \\
\hline & & \multicolumn{2}{c}{ Collinearity Statistics } \\
\cline { 2 - 4 } & Model & Tolerance & VIF \\
\hline 1 & (Constant) & & \\
\cline { 2 - 4 } & ROA & 1.000 & 1.000 \\
\hline
\end{tabular}

a. Dependent Variable: PBV

Sumber data : data diolah

Berdasarkan hasil dari tabel 2 yang menunjukkan nilai Tolerance 1 dan VIF 1 sehingga tidak ada gejala multikolinieritas.

\section{Uji Heteroskedatisitas}

Gambar 2. Hasil Uji Heteroskedastisitas - Scatterplot

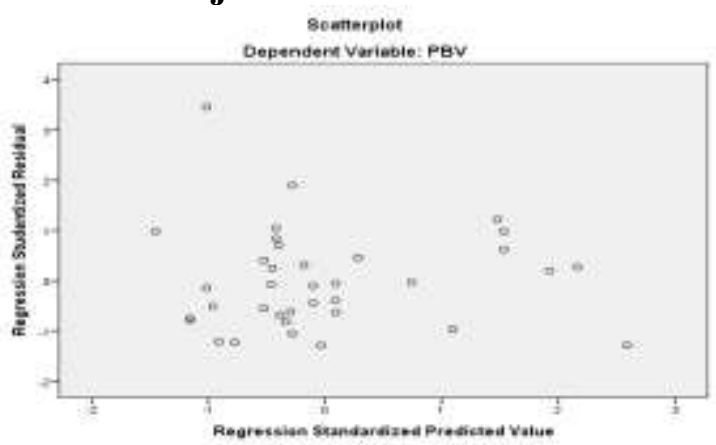

Sumber data : data diolah 
Dari grafik diatas tampak bahwa titik-titik dalam grafik menyebar dengan acak dan tidak membentuk pola tertentu, sehingga tidak ada gejala heteroskedastisitas.

\section{Uji Autokorelasi}

Tabel 3. Hasil Uji Autokorelasi - Runs Test

\begin{tabular}{lr}
\hline \multicolumn{2}{c}{ Runs Test } \\
\hline & $\begin{array}{l}\text { Unstandardiz } \\
\text { ed Residual }\end{array}$ \\
\hline Test Value $^{\mathrm{a}}$ & -5.02321 \\
\hline Cases < Test Value & 16 \\
\hline Cases >= Test & 16 \\
Value & 32 \\
\hline Total Cases & 15 \\
\hline Number of Runs & -1.174 \\
\hline Z & .227 \\
\hline Asymp. Sig. (2- & \\
tailed) & \\
\hline a. Median & \\
\hline
\end{tabular}

Sumber data : data diolah

Berdasarkan dari data diatas menunjukkan bahwa nilai Sig sebesar 0.227. sehingga tidak ada gejala autokorelasi dalam penelitian ini.

\section{Pengujian Hipotesis}

\section{Analisis Regresi Linier Sederhana}

Tabel 4. Hasil Analisis Regresi Linier Sederhana

\begin{tabular}{|c|c|c|c|c|c|c|}
\hline \multicolumn{7}{|c|}{ Coefficients $^{\mathrm{a}}$} \\
\hline & \multirow{5}{*}{ Model } & & & \multirow{5}{*}{$\begin{array}{c}\text { Standardize } \\
\mathrm{d} \\
\text { Coefficient } \\
\mathrm{s} \\
\text { Beta }\end{array}$} & \multirow{5}{*}{$\mathrm{T}$} & \multirow{5}{*}{ Sig. } \\
\hline & & & & & & \\
\hline & & \multirow{2}{*}{\multicolumn{2}{|c|}{ Coefficients }} & & & \\
\hline & & & & & & \\
\hline & & B & Std. Error & & & \\
\hline \multirow[t]{2}{*}{1} & $\begin{array}{l}\text { (Constan } \\
\text { t) }\end{array}$ & 539.127 & 201.643 & & 2.674 & .011 \\
\hline & ROA & 18.679 & 2.709 & .764 & 6.896 & .000 \\
\hline
\end{tabular}

a. Dependent Variable: PBV

Sumber data : data diolah 
Moderated Regression Analysis (MRA)

Tabel 5. Hasil MRA

\begin{tabular}{|c|c|c|c|c|c|c|}
\hline \multicolumn{7}{|c|}{ Coefficients $^{\mathrm{a}}$} \\
\hline & \multirow[t]{2}{*}{ Model } & \multicolumn{2}{|c|}{$\begin{array}{l}\text { Unstandardized } \\
\text { Coefficients }\end{array}$} & \multirow{2}{*}{$\begin{array}{l}\text { Standardize } \\
\text { d } \\
\text { Coefficients } \\
\text { Beta }\end{array}$} & \multirow[t]{2}{*}{$\mathrm{T}$} & \multirow[t]{2}{*}{ Sig. } \\
\hline & & $\mathrm{B}$ & Std. Error & & & \\
\hline \multirow[t]{5}{*}{1} & (Constant) & 562.237 & 203.097 & & 2.768 & .009 \\
\hline & $\mathrm{ROA}$ & 11.606 & 8.901 & .474 & 1.304 & .202 \\
\hline & ROA*KA & -14.314 & 8.298 & -.299 & -1.725 & .095 \\
\hline & ROA*KI & 26.069 & 21.321 & .482 & 1.223 & .231 \\
\hline & ROA*KM & 13.542 & 8.945 & .201 & 1.514 & .140 \\
\hline
\end{tabular}

a. Dependent Variable: PBV

Sumber data : data diolah

Dari hasil SPSS pada tabel 4 dan 5 menunjukkan bahwa profitabilitas berpengaruh terhadap Nilai Perusahaan. karena nilai sig yang dihasilkan pada tabel 4 sebesar 0.000 lebih kecil dari 0.05 Sedang untuk hasil MRA diatas 0.05 yang artinya tidak ada variabel yang memperkuat hubungan antara profitabilitas dengan nilai perusahaan. Tampak nilai signifikansi ROA*KA adalah 0.095, ROA*KI adalah 0.231 dan ROA*KM adalah 0.140 .

Hipotesis pertama yaitu profitabilitas berpengaruh terhadap nilai perusahaan. Dari hasil uji parsial (uji t) diperoleh hasil nilai t-hitung $>$ t-tabel $6,896>2,0345)$ dan nilai signifikan $<0,05(0,000<0,05)$ sehingga membuktikan profitabilitas berpengaruh positif signifikan terhadap nilai perusahaan. Sehingga, dapat dikatakan bahwa H1 yang menyatakan bahwa profitabilitas berpengaruh terhadap nilai perusahaan diterima. Komite audit menjadi proksi GCG menghasilkan nilai signifikan 0,095 > 0,05 dan t-hitung $-1,725<2,0345$, yang artinya GCG dengan proxy komite audit tidak memoderasi hubungan profitabilitas terhadap nilai perusahaan. GCG dengan proxy komisaris independen menghasilkan nilai signifikan sebesar 0,231 >0,05 dan t-hitung 1,223 < dari ttabel 2,0345, sehingga GCG dengan proksi komisaris independen tidak memperkuat hubungan profitabilitas terhadap nilai perusahaan. GCG menggunakan proksi kepemilikan managerial menghasilkan nilai signifikan 0,140 $>0,05$ dan nilai t-hitung 1,514 < dari t-tabel 2,0345 sehingga GCG dengan proksi kepemilikan managerial tidak memoderasi antara profitabilitas terhadap nilai perusahaan.

Dari hipotesis 2 maka disimpulkan bahwa GCG tidak memperkuat atau tidak memoderasi hubungan profitabilitas terhadap nilai perusahaan.

\section{KESIMPULAN DAN SARAN}

Dari hasil uji analisis dengan menggunakan regresi linier sederhana maka disimpulkan bahwa Profitabilitas berpengruh positif signifikan terhadap nilai perusahaan. Dari pengujian parsial dihasilkan nilai t-hitung > t-tabel 6,896> 
2,0345) dan nilai signifikan $<0,05(0,000<0,05)$ sehingga menggambarkan bahwa terdapat pengaruh yang signifikan antara profitabilitas terhadap nilai perusahaan.

Dari hasil pengujian analisis MRA dinyatakan bahwa yang pertama variabel moderasi GCG menggunakan proksi komite audit menghasilkan nilai signifikan 0,095 > 0,05 dan t-hitung -1,725 <2,0345, dimana GCG dengan proksi komite audit tidak memoderasi atau memperlemah hubungan profitabilitas terhadap nilai perusahaan. Kedua, GCG dengan proksi komisaris independen yang menghasilkan nilai signifikan sebesar $0,231>0,05$ dan t-hitung $1,223<$ dari $\mathrm{t}$ tabel 2,0345, artinya GCG dengan proxy komisaris independen tidak memoderasi atau tidak memperkuat hubungan antara profitabilitas dan nilai perusahaan. Ketiga, variabel GCG dengan proksi kepemilikan managerial menghasilkan nilai signifikan 0,140>0,05 dan nilai t-hitung 1,514 < dari t-tabel 2,0345, sehingga menggambarkan bahwa GCG dengan proksi kepemilikan managerial dapat tidak memperkuat hubungan profitabilitas terhadap nilai perusahaan.

\section{DAFTAR PUSTAKA}

Bintara, R. (2018). Pengaruh Profitabilitas, Growth Opportunity, Dan Struktur Modal Terhadap Nilai Perusahaan Dengan Good Corporate Governance Sebagai Variabel Pemoderasi (Studi Empiris Pada Perusahaan Manufaktur yang Terdaftar di Bursa Efek Indonesia Tahun 2012-2015). Jurnal Profita: Komunikasi Ilmiah Akuntansi Dan Perpajakan, 11(2), 1-58.

Cahyaningrum, Y. W., \& Antikasari, T. W. (2017). Pengaruh Earning Per Share, Price To Book Value, Return On Asset, Dan Return On Equity Terhadap Harga Saham Sektor Keuangan. Jurnal Economia. https://doi.org/10.21831/economia.v13i2.13961

Fajrian, H. (2019). Sektor Barang Konsumi Melesat Nyaris 2\%, IHSG Tembus 6.328,71. Katadata.Co.Id, 1. Retrieved from https://katadata.co.id/happyfajrian/finansial/5e9a5576c5234/sektor-barangkonsumi-melesat-nyaris-2-ihsg-tembus-632871

Fasya, A. (2019). Pengaruh Pengungkapan Corporate Social Responsibility Terhadap Nilai Perusahaan Dengan Profitabilitas Sebagai Variabel Pemoderasi. Jurnal Informasi, Perpajakan, Akuntansi, Dan Keuangan Publik. https://doi.org/10.25105/jipak.v13i2.5012

Hariadi, S., \& Sari, I. S. W. (2021). Efek Moderasi Kualitas Tata Kelola Perusahaan Dari Pengaruh Modal Intelektual dan Pengungkapan Tanggung Jawab Sosial Perusahaan terhadap Kinerja Pasar. Jurnal Akuntansi Dan Manajemen, STIE Indonesia Jakarta, 18(02), 82-90.

Kuswandi, N., \& Indriyani, R. (2020). Analisis Penerapan Good Corporate Governance Pada Perusahaan Keluarga Pt. X. Jurnal Ekonomi Manajemen Sistem Informasi, 1(3), 248-260. https://doi.org/10.31933/jemsi.v1i3.106

Lo, E. W. (2012). Pengaruh Tingkat Kesulitan Keuangan Terhadap Manajemen Laba: Teori Keagenan Versus Teori Signaling. Jurnal Riset 
Akuntansi Dan Keuangan, 8(1), 1. https://doi.org/10.21460/jrak.2012.81.27

Mufidah, N. M., \& Purnamasari, P. E. (2018). Pengaruh Profitabilitas Terhadap Nilai Perusahaan Dengan Pengungkapan Corporate Social Responsibility Dan Good Corporate Governance Sebagai Variabel Moderating. El Dinar, 6(1), 64. https://doi.org/10.18860/ed.v6i1.5454

Nanda, A. J., \& Fajar, S. S. (2021). Determinasi Pengungkapan Corporate Social Responsibility: Studi Empiris Pada Perusahaan Manufaktur Yang Terdaftar di Bursa Efek Indonesia. Jurnal REKSA: Rekayasa Keuangan, Syariah, Dan Audit, 08(02), 100-117. Retrieved from http://journal2.uad.ac.id/index.php/reksa/article/view/2264

Puspitasari, D., \& Suryawati, B. N. (2019). Pengaruh Profitabilitas Terhadap Nilai Perusahaan dengan Good Corporate Governance Sebagai Variabel Moderasi pada Perusahaan Makanan dan Minuman yang Terdaftar di Bursa Efek Indonesia Periode 2014-2017. Jurnal Sosial Ekonomi Dan Humaniora, 5(1), 17-26. Retrieved from http://jseh.unram.ac.id

Raharjo, E. (2007). Teori Agensi Dan Teori Stewarship Dalam Perspektif Akuntansi (Agency Theory Vs Stewardship Theory in the Accounting Perspective). Jurnal Ilmiah Ekonomi, 2(1), 37-46. https://doi.org/10.1142/9789814632775_0003

Sarafina, S., \& Saifi, M. (2017). Pengaruh Good Corporate Governance Terhadap Kinerja Keuangan dan Nilai Perusahaan ( Studi pada Badan Usaha Milik Negara ( BUMN ) yang Terdaftar di Bursa Efek Indonesia Periode 2012-2015). Jurnal Administrasi Bisnis (JAB).

Wijaya, A. L., \& Pancawati, E. L. (2019). Pengaruh Pengungkapan Corporate Social Responsibility (CSR) dan Profitabilitas terhadap NIlai Perusahaan dengan Struktur Modal sebagai Variabel Pemoderasi (Studi Pada Perusahaan Food and Beverage Tahun 2013-2017). INVENTORY: Jurnal Akuntansi, 3(2), 131-140. 